\title{
The Implications of the Legislative Corrupt Practices on the Democratic Consolidation in the Nigeria's Fourth Republic
}

\author{
Yusuf Abdu Yusuf ${ }^{1 *}$, Kamarul Zaman Haji Yusoff ${ }^{2}$, Knocks Tapiwa Zengeni ${ }^{3}$
}

${ }^{1}$ Department of Public Administration

Bauchi State University, Gadau, NIGERIA

${ }^{2}$ School of International Studies

Universiti Utara Malaysia, MALAYSIA

${ }^{3}$ Department of Public Administration

Bauchi State University, Gadau, NIGERIA

*Corresponding Author : yusufudarazo@gmail.com

DOI: https://doi.org/10.30880/jts.2018.10.01.002

\begin{abstract}
This study analyses the corrupt practices in the Nigerian democracy with specific reference to national legislatures. Using thematic analysis after conducting semi structured interviews, the paper argues that, legislative corrupt practices have become one of the greatest threats to the Nigeria democratic consolidation; it reveals that, corrupt practices are responsible for the poor implementation of public policies in health, education and other infrastructures, it also contributes to the youth unemployment, poverty and national crisis. The paper opines that, corrupt practices of legislative members are inimical and obstacle to democratic consolidation in Nigeria, since the legislature is an institution that is expected to consolidate democracy. Until the institution has been strengthened in its oversight function, scrupulous screening of the legislature is undertaken before the election, the strengthening of recall back mechanism, and the comprehensive approach to deter corrupt practices by the anti-graft institutions, consolidated democracy would not be attained in Nigeria.
\end{abstract}

Keywords: Implications, Legislature, Democratic Consolidation and Corrupt Practices.

\subsection{Introduction}

The legislative corrupt practices have become one of the most widely concept among social scientists, whenever the issue of democratic consolidation and development are discussed (Olutola \& Isaac, 2016). In Nigeria, the involvement of the legislature in the corrupt practices has led to the loss of the citizen confidence in the political system, because they considered legislative members as corrupt representatives that are no longer adhere strictly to the due process and the rule of law.

The legislature has been severally indicted for the corrupt practices in Nigeria, as they are often involved in accepting bribe for the passing of appropriation bills or awarding of contracts for selfish interest (Otusanya, 2010). This is an aberration in the democracy, since the legislature as it has been argued, are very significant institution of curving anti-social problems through their role of legislation and oversight function (Stapenhurst et al., 2006; Oyewo, 2007).

Surprisingly, the institution which is constitutionally offered with the responsibility of curbing corruption, is itself not immune from the practice (Alabi \& Fashagba, 2010). Corrupt practices in the representatives of the citizen can affect the process of democratic consolidation, since it may hinder and rob their moral ground to challenge the executive members that are engaged in the corrupt practices. Consolidation entails both the eradication of the residue of dictatorial system that is incompatible with the practice of the democratic regime and establishment of mechanism 
which ensure accountability in the entire political system (Ahmed, 2011). What will actually promote democratic consolidation is when public and political office holders are regularly answerable and accountable to the citizens.

Corruption is a phenomenon that is complex, socially, politically and economically, it has widely affected all countries around the world. The history of corruption is a as old as the world itself, as the fact, that antiquated civil establishment have indirectly suggested a common "wrongness and debasement (Dike, 2005; Olutola, 2016; Banidele $\&$ Ayodele, 2016). Corruption can be said to facilitate a myriad of problems in many countries, and its effects are corrosive and inimical to the democratization process. It is one of the most important factors in reversing and impeding the democracy and economic development. Also, it has overwhelming effects on the basis of the democracy and its institutions; most especially the institution of the legislature, which plays the role of the lawmaking as well as the oversight functions that ensures checks and balance.

Several findings from the previous studies had evidently revealed the colossal evil and impact of corruption on democracy and economy in the form of less culture of accountability, excessive concentration of power in arms of government, lack of transparency, stealing public property, inefficiency, weak government structures and institutions, mismanagement of resources which usually emanated due to the failure from the part of politics and the democratic project and its consolidation.

Since the re-emergence of democracy in Nigeria in 1999, there have been a several feelings which are assumed to be mixed in any case, about the role of each arm of government in Nigeria (Stapenhurst, Jacob \& Olaere, 2016). A plethora of writings, both in the newspaper and other literary outlets have demonstrated that the legislature is characterized by a number of conglomerations of attitudes, which may be considered to be both positive and negative (Ogundiya, 2010; Punch, 2012; Ekong, 2015 Okeke, \& Idike, 2016). In case, this paper finds it very significant to study the implications of legislative corrupt practices on the democratic consolidation in Nigeria.

Existing studies in legislative corrupt practices in Nigeria are primarily not empirical, and fall short of studying the implications of its practices to democratic consolidation. Such studies include; (Stapenhurst, Johnston \& Pelizzo, 2006; Otusanya, Lauwo, Ige, \& Adelaja, 2015; Olutola \& Isaac, 2016). Although, this study does not provide a holistic analysis of the corrupt practices, instead, it focuses on the negative side of legislative practice by studying its implications on democratic consolidation in Nigeria's fourth republic.

Corruption has contributed to the slow process of democratic consolidation in Nigeria, right from First Republic (1960-1966), the Second republic (1979-1983.). However, it was observed that from the previous republics to the present, the major threat to democracy is the attitudes of the legislature, and political actors, not complying with basic principles of the rules of the game (Nwosu, 1998; Ajayi, 2007). Unfortunately, even the military usually presents corruption as their justification for military intervention into politics, though, similar culture also had characterized the military rule in Nigeria. It is based on these that, this research engages in the study of the corrupt practices of the Nigerian legislature and its implications on the democratic consolidation, through interview with informants, a solution to the phenomenon is also suggested. Therefore, to clearly understand the corrupt practices of the legislature, questions were posed, first, what is the nature of corrupt practices in the Nigerian National Assembly? What are the implications of these corrupt practices on democratic consolidation in the Nigeria fourth republic? What are the best possible ways of tackling corrupt practice in the National Assembly? The paper has critically engaged in answering such questions.

\subsection{Literature Review}

There is no universally accepted meaning or definition of corruption, several views had been put forward from different standpoints. What is generally agreed is that the concept has been associated with unwholesome practices in the society that is more often than not linked to political, economic and social problems. The concept is not easy to define, because it has ramification and facets. According to Pope (2006), Transparency International (TI) viewed corruption as misuses of entrusted power for private benefit. This definition can be regarded as narrow, as it only suggested corruption to occur in the public sector. Meanwhile, corruption transcendent to all most all the sectors of life.

According to Transparency International (2015) corruption can be categorized as pretty, grand as well as political, what determines it, is the quantity of cash lost or where the incident occurs. However, for the purpose of this paper, corruption can be considered as abuse of public office or trust for the benefit of oneself or group that ones pay allegiance. The benefits can be monetary, privileges or anything intangible. The people that are entrusted with public office are expected to be accountable to the public. Whenever corruption thrives most especially in the important institutions of government, it undermines the values of democracy. Corruption in governmental institutions led to that of an individual, thereby, making the whole system to be corrupt. Dukor (1990) has this to say,

\footnotetext{
'Hence, corruption has endemic, cancerous and oracular tendencies. It is endemic because it normally catches up with a people or community, it is cancerous because it spreads from one person to the other until it engulf the whole society. It is equally oracular in nature because once it spreads in a system, people tend to believe in it, just as people of ancient times believed in and worshipped oracles. In a corrupt society, people tend to think that, no one can be successful without being corrupt. Secondly, corruption can easily be located among the powerful. It is mostly privileged and powerful that can easily become corrupt.'. (Dakar, 1990: xi).
} 
Anderson \& Tverdova (2003) and Warren (2004) have in separate works, observed that, serious act of corruption really undermines the credibility and legitimacy of government. It was generally agreed that, it is impossible to quantify the impact of corruption on undermining the democratic system by penetrating the highest as well as a basic level of public services (AAPPG, 2006; Otusanya, 2011).

The principle of democratic systems presumes that, government and its arms are accountable to their citizens. Therefore, political scientists have long postulated that political systems that failed to live up to these promises are likely be plagued by low levels of credibility and legitimacy (Anderson \& Tverdova, 2003). It has been also argued that public officials are likely to be self-centred, thus, institutions of democracy should be structured to ensure that no public official has monopoly of control and power over resources; the power they do have, should be linked to the mechanism of accountability, and the rules under which they operate should be relatively clear and minimize opportunity for discretionary judgment (Gardiner \& Lyman, 1978; Rose-Ackerman, 1999; Transparency International, 2001; Johnston, 2005).

Furthermore, from the existing literature, there is widespread consensus that, the rate of corrupt practices is higher in developing countries (Olken, 2007; Olken, 2009 \& Pande, 2012). Though, similar problem can be found in a developed countries, as evidence shows that, there is an increase rampant corruption scandal in almost all the states in U.S (Facchini \& Testa, 2016). There are a series of three corrupt practices investigation and conviction in California, which consequently tarnished the image of the Golden state, and in effect, it cost the democrat party three seats. The case generated a great deal of media attention. This has denied the party its super majority power in the senate (Diasorro \& Hussey, 2016).

However, cases of high profile political actors resorting to corrupt practices can be found everywhere across the world (Garten, 2016). Corruption in Nigeria has been taken a center stage most especially with the returned of democracy in 1999, this is being witnessed in the period whereby, the Nigerians are expecting an unprecedented change in the political system and general life of the people. Some of the examples of the corrupt practices of the legislature in Nigeria include; the saga of petroleum subsidy with a former member of the Senate, Faruk Lawan and C.E.O of capital oil Otedola Femi. Similarly, the corruption case involving former speaker of the house of representative Dimeji Bonkole (Halilu, Garba \& Abdulmumin, 2015; Uwak \& Udofia, 2016).

It was also observed that, nepotism and corruption have become the order of the day in the legislative arm of the Nigerian government, to the extent that, the bill would be hardly passed by the legislature until the members of parliament have their hands greased. One of the implications of this phenomenon is that, debate on bill at whatever level can not be subject to scrutiny in the interest of electorates, who are actually the sources of that bill.

Furthermore, to contribute to the discourse of elite financial crime Otusanya, Lauwo and Adelaja (2015) have conducted a study with particular attention to the role of the legislature in corrupt practices in Nigeria. The paper argues that, a political system that embedded with discretion, monopoly and with low or no accountability, facilitated corruption. Their findings show that, it is the inability of the regulator to seriously sanction legislators found with corrupt practice, that actually provide a fertile ground for the corrupt practices in the Nigeria's democracy. In other words, the problem is the presence of regulatory bodies that are not sufficiently equipped to deal with financial crime of the legislature.

Otusanya (2011), posited that the democratic system in Nigeria is threatened by an unprecedented increase in corruption that has happened since the dictators of the past have left the arena. His paper argued that, corruption has seriously increased under democracy in Nigeria, and points to various factors that are responsible for the increase. The dispersion of power in the hands of many has improved the opportunity for corrupt practices.

Recently, Odisu (2016) has studied the crises of governance in the Nigerian legislature using qualitative analysis, he studied the performance of the parliament of both federal and state levels between 1999-2016, investigating the improvement in good governance in the country, the study identified corruption as main reason for the ineffectiveness of the Nigeria legislature. He recommended that it is imperative to reform the leadership recruitment process in the country, so that unblemished and patriotically Nigerians will be given the chance into politics to contest for parliamentary seats.

\subsection{Research Methods}

The methodology employed in this paper is a qualitative approach via the telephonic interview technique of data collection. The advantage of this technique is that, it provides wide geographical access, most especially to those with closed access. Moreover, it consumes little time and resources, compare to a face to face interview (Opdennaker, 2006). The paper is largely interpretive and additionally, purposive sampling was adopted in recruiting the 7 respondents, who are staff of legislative institute and members of academia who are experts in legislative and corruption studies. This method is used because the interviewees are some of the relevant people to generate from them relevant information. Thereby, using secondary sources of data to support their responses. The interview data were subjected to the managing procedures by first organizing the data, the preliminary reading of database, coding, transcribing, thematic organization, representation and forming an interpretation of them as Creswell (2013) pointed out. This will enable the researcher present reliable and precise results. 


\subsection{Findings and Discussion}

Following the themes that emerged from the technique of analysis, the themes were categorized into further subthemes that were analyzed in relation to the original narration of respondents. Thus, this assisted to achieve stated objectives through the indepth opinion of the interviewees. The nature and implications of legislative corrupt practices to the democratic consolidation were analyzed.

\section{The Nature of Legislative Corrupt Practices in Nigeria}

The nature of corrupt practice in the legislative arm manifests itself in many ways, the most recent one is the issue of padding the 2016 budget proposal, by incorporating things that are outside legal framework or what had been submitted by the president for appropriation. This has been reiterated by most of the respondents, while others, specifically 1st, 2nd, and 7th interviewees emphasized that, the nature of legislative corrupt practices is both administrative and political, which includes, among other things; constituency project scams and inside dealings with the executive branch, as way and manner in which legislature indulges in corrupt practices. Moreover, some are of the view that, Politics in Nigeria are pursued as a zero sum game and it is considered an avenue for self-enrichment rather than service to the people, this made some legislators to involve themselves in a financial crime as disclosed by one of the respondents;

Records have indicated that, most of the corrupt practices were those of financial bribery and scandals involving either the NASS leadership, and the various committee members. There are allegations several cases of financial misconduct against some senators in the fourth republic. For example, in July 2000, an investigative panel found evidence of inflated procurement contracts in the National Assembly, some unregistered companies were contracts in which legislators had a financial interest. This led to the impeachment of the senate president in the year, 2000 (Interviewee, 3).

Similarly, this has been confirmed by Abraham (2016) where the Senate leadership was found guilty of inflated figures by the ad hoc committee of investigation as he was indicted by the Accountant General's audit report, Chuba Okadigbo was recommended by the committee to resign, his refusal to accept the committee recommendation caused his removal from the position of senate president. The above committee was led by Senator Idris Kuta, and the series of allegation was on the street light project, furnishing and install and commission of $100 \mathrm{KVA}$ set in the senate president residence. Furthermore, the same Interviewee lamented that, the legislature is characterized by numerous forms of corrupt practices, as he observed;

The National Electric Power Authority 16 billion Naira allegations against the committee members set up to investigate, the matter ended being corrupt in the year 2007. Another financial corrupt practice is the 2012 fuel subsidy regime allegation, level against legislative committees, following the removal of subsidy on oil. The repercussions were industrial strike actions among other reactions in the country. The committee discovered about 18 oil companies that were not registered but collected subsidy on fuel illegally from the federal government. A legislative committee set up to investigate the scandals ended with fruitless results of even receiving bribes (Interviewee 3).

This is supported by the findings of Adeoson (2014) about the issue of oil subsidy that rocked the NASS. These scandals from the strong institution of democracy had demonstrated the level and the nature of corrupt practices of the legislature in Nigeria's fourth republic. Moreover, as the 3rd and 7th interviewees observed, the legislators usually connive with the head of the agencies and ministries to perpetrate corruption, that is why one respondent has the following words to say;

The minister of education in March 2005, was eliminated for allegedly bribing the National Assembly to secure more funds for the ministry. A senate president resigned due to allegations of financial bribery. The senate committee on Health also was enmeshed in two different financial scandals (interviewee 3).

In a study conducted by Abraham, (2016) he rightly observed that, Adolphus Wabara who was the Senate leader in 2003-2005 and was caught with another Senator in a web of bribe with the federal minister in a budget scandal. The most unfortunate is that, all of the respondents concurred that, The anti-graft agencies were jeopardized in combating corruption, especially at the legislature in the last sixteen years. In fact, the 3rd respondent is of the view that the antigraft agencies themselves sometime aid corruption. In a like manner, Onuigbo (2015) observed that, the creation of Economic and Financial Crimes Commission (EFCC), Independent Corrupt Practices and other related Commission (ICPC), as well as the Code of Conduct Bureau and its tribunal, though, has registered little success, but they have gone after the tail of the monster of corruption rather than its heads. Moreover, Otusanya, at, el., (2015) find out that, one of the implications of an elite financial crime is the inability of the regulators to effectively apprehend the legislators in corrupt practices, because the present regulatory institutional apparatus are not well equipped in dealing with financial 
crime of the legislature. This clearly shows that, anti-graft agencies do not give much attention to most of the corrupt practice happening in the National Assembly (NASS).

Furthermore, there are several factors that account for the corrupt practices in the legislature, the 1st, 2nd, 4th, 5th and 6th respondents agreed that, factors responsible for corrupt practices in Nigerian legislatures are so enormous: despite the jomboo salary and allowances offers to them from federal government, the executive use to give them bribe to facilitates their self-centric mission in government, the 55 million naira bribe from former Minister of education, in person of Professor Fabian Osuji to the senate and House of representative committee on education, is a classical illustration, this led to the removal of senate President Adolplus Nwabara and other key principal officers like Senator Jonathan Zangina and Member Dr. Shehu Matazu from their position as the chairmen of committees on education in their respective houses. Moreover, Otusanya, at, el., (2015) argued that, political institutions embedded structurally with discretion and monopoly and with little or no accountability helped in financial corrupt practices in the legislature.

Similarly, Banjo (2013) proved in his analysis that, the senate of national assembly that started from 1999 to 2007 were actually involved in a financial scandal as well as a crisis in leadership, and this, demonstrated characteristic of the legislature in corrupt practices. Therefore, the nature of Nigerian legislative corrupt practices, as demonstrated by the current findings and supported by the previous research can be considered both political, administrative, and financial. These have implications for democracy and the entire political system.

\section{The Implications corrupt practices to the Democratic Consolidation}

Previous studies have supported the view of all respondents, that corruption most especially by a particular institution of government is inimical to democracy and its consolidation (Ogundiya, 2010; Otusanya, Lauwo, Ige, \& Adelaja, 2015; Olutola \& Isaac, 2016). Constitutional democracy depends on its institutions for its sustenance. One of the respondents reiterated that;

The legislature is the public watchdog over public office and public office holders, and if the legislature is corrupt, then democracy is in danger (Interviewee 4).

Similarly, some informants lamented that, Corruption is a serious hurdle to the consolidation of the Nigerian`s democracy, hence corrupt practices has led to poor implementation of public policies in education, health and other infrastructure. It also led to youth unemployment, poverty and national crises. Corruption has gone deep into the political process in the country. Many of the respondents conceived legislative corrupt practices as an obstacle to the democratic consolidation, because, the lawmakers cannot make good laws for the protection of the entire citizens, and the executive would use ill-gotten money from contractors, such as kickback or extortion to compromise the standard for doing good and effective capital projects to the public. While the private sector can go contrary to efficiency and efficacy in service delivery, because they have a back up from those who are in government. In fact, corruption has hindered the development and economic growth to thrive in Nigeria. Suffice to illustrate an example with the issue of electricity in the country, where huge amount money was spent, but still the country is in unstable power supply

Furthermore, respondent 7 th described the corrupt practices of the legislature as a serious impediment to democracy, because the legislature is one of its strongest pillars, with such kind of practice in the institution of democracy, then of course, the future of democracy has been blocked, therefore corruption is inimical to the actual practice of democracy, most especially a fledgeling one like that of Nigeria. It was previously observed in separate works by Oko (2008) and Adeoson (2014) that, nothing retarded democracy more than corruption and mention some of corruption scandals in the Nigerian national assembly. This is, perhaps, because corruption involving and perpetrating by policy makers is very difficult to fight, and it constituted a great challenge to democratic consolidation (Adeoso, 2014). Consolidating democracy requires the contribution and active role of the legislature, since, one of the democratic institution that is highly assumed to improve democracy is the legislature (Izah, 2013). Looking at these anomalies in the Nigerian legislature, then democratic consolidation has been call to a question. It is only when a legislature observed the principle of rule of law and due process, democracy will thrive.

\section{A Panacia to Corrupt practices in the Nigerian Legislature}

It was observed by some respondents that, lack of sound and effective measures from anti-graft institutions, legal services and judiciary system are all the rudiments that makes corrupt practices to become highly persistent in the legislature. Therefore, there is a need for a comprehensive approach to curtail it from all levels most especially legislature. One of the respondents suggested that;

The is a need for a holistic approach from the anti-graft agencies, and the application of laws and the extant regulations for all citizens in line with the principle of rule of law, so as to prosecute whoever indicted among the members of the national assembly, without fear or favor. In fact, there are sacred cows as former president Obasanjo said, let each members ranging from the principle officers to flow members be prosecuted and punish in accordance with the extant regulation. For instance, when Salisu Buhari was indicted with falsification of age and fake certificate, let him be jailed for 7years as prescribed for fake certificate holders not just to pardon him alone, 
so as to serve as a lesson to the entire members and the general public. This is what we called leadership by example within the context of governance. (Interviewee 1).

Both respondents $1 \mathrm{st}, 2 \mathrm{nd}, 3 \mathrm{rd}, 4 \mathrm{th}, 5$ th and 7 th have concurred that there is a need for the electorates to choose the right people to represent them, similarly, anti graft agencies needs to be strengthened.

Electorates should vote for the responsible people into office and institutions should be put in place that can fight corruption. Immunity should also be removed. Accused persons should be arrested where ever they are found (Interviewee 4).

Other respondents have also expressed their concerned over corrupt practices in the legislature and suggested that there is a need for credible leadership in both two chambers, of the National Assembly, empowerment of the judiciary and security agencies to trial as well as apprehend any member that disorder the statutory provision of the constitution. Furthermore, they suggested that, regular assessment of legislature's performance by the political parties, constituencies and the national assembly commission will reduce the practice. Similarly, the Independent National Electoral Commission (INEC) should conduct a scrupulous screening of candidates before elections. It should discourage the use of money to persuade support for any candidate by the electoral commission, and the commission should also for the matter of urgency redevelop its mechanism of recalling back any member of the legislature that is under performing and corrupt. This also requires an enlightenment to the Nigerian people, as many are not literate enough to employ recalling back principle. In a similar vein, the legislature need to be strengthened to perform its oversight function effectively through the insistence of transparency and the rule of law in the national assembly.

\subsection{Conclusion}

Within the Islamic perspectives of spirituality and religion, the Jeedo share similarity with examples like suluk and Pondok among others. The Jeedo shares similarity to other systems religious engagement in the religious and spiritual engagement of elderly people. Similar to "Suluk" which literally means take a path or road, the Jeedo in relation to the religion of Islam and Sufism, also means the path of spirituality through diligence. This creates a feeling of being on right path leading to a perfect relationship with Allah, in form of Recourse (bersuluk). However, while the suluk includes a lifelong discipline in abiding by the Shari'a and esoteric Islamic explanations of nature and the way things occur, the Jeedo steps ahead as preparation for death.

Like the word "salik" which comes from the terminology of the Qur'an, Fasluki, meaning Someone who took the road, usually associated with Sufism, the word Jeedo comes from the literal perception of the works of Sayyida Maryam (AS) based on her zeal and commitment to duty in the Mosque and the service of Allah. This made the Jeedo adherents similar to the a salik as someone who undergoes a spiritual discipline to cleanse and purify the soul. Again, the motive is similar, since for the Jeedo also the goal is to pave the way for death in faith "iman" . Therefore, the totality of the Jeedo practice means to constantly keep the parts of the body and the heart occupied in the obedience of Allah Most High. These include all the activities and duties of the congregation and the core 70, in addition to the wider Jeedo network.

Another practice is referred to as the Pondok system which shares similarity also in the aspect of spirituality and a platform for devotion. Similar to the Jeedo, with regard to education, the 'Pondok' originated mainly as ' Religious schools among the Malay ethnic group. (Khoo, 1991). Similarly, the account of nana Asama'u indicates educational services by elderly women as the origin of the Jeedo from the caliphate both were therefore, inspired by the spread of Islam.

Similar to the Pondok, the Jeedo as well provides a bases for Islamic Education, and means for spending old age in spiritual devotion. It is similarly a way to seek for continual religious education. In addition, both systems regard, Spiritual well-being of the elderly as the main goal. (Sufian and Mohamad, 2013).

\section{References}

AAPPG (2006), "The other side of the coin: the UK and corruption in Africa", A Report by the Africa All Party Parliamentary Group.

Abraham, O. L. (2016) The Politics of Leadership Instability in Nigeria's Senate, 1999-2011. International Journal of Politics and Good Governance, Volume VII, No. 7.1

Adeosun, A. B. (2014). Democracy And Democratic Consolidation In Nigerian Fourth Republic: Issues and Challenges. Journal of Humanities and Social Science (IOSR-JHSS) Vol, 19, 05-10. 
Ahmed, N. (2011). Parliament and Democratic Consolidation in Bangladesh. Australasian Review, 26(2), 53-68.

Alabi, M.O.A. and Fashagba, J.Y. (2010), "The legislature and anti-corruption crusade under the fourth republic of Nigeria: constitutional imperatives and practical realities", International Journal of Politics and Good Governance, Vol. 1 No. 1, pp. 1-39

Anderson, C.J. \& Tverdova, Y.V. (2003), “Corruption, political allegiance, and attitudes toward government in contemporary democracies", American Journal of Political Science, Vol. 47 No. 1, pp. 91-109.

Bamidele, O., Olaniyan, A. O., \& Ayodele, B. (2016). Culture, Corruption, and Anticorruption Struggles in Nigeria. Journal of Developing Societies, 32(2), 103-129.

Banjo, A. 2013. "Leadership Crisis in the Parliament of Nigeria: The Case of the Senate in the Journal of African Studies and Development, 5(6): 135-144

Barkan, J. D. (2008). Progress and retreat in Africa: Legislatures on the rise? Business and Social Sciences, 1998 , vol. $5,31-49$.

Creswell, J. W. (2013). Research design: Qualitative, quantitative, and mixed methods approaches. Sage publications.

Dike, V. E. (2005). Corruption in Nigeria: A new paradigm for effective control. Africa economic analysis, 24(08), 122.

DisSarro, B., \& Hussey, W. (2016). California's 2014-15 Budget: Political Corruption Distracts the State. California Journal of Politics and Policy, 8(1).

Dukor, M. (1990). Corruption and Social Action in Nigeria. In Philosophy and Social Actio: Philosophy, Science, and Society vol. 16, No.2

Ejere, E. S. I. (2004): “Democracy, Human Rights, Rule. Nigerian Journal of Political Science.

Ekong, C. N. (2015). Corruption in Nigeria: An Attempt at Modeling Eradication Strategies.

Emmanuel, N., \& Emmanuel, C. N. (2015). Examining the Challenges of Democratic Consolidation in Nigeria: The Way Forward.

Fagbadebo, O., \& Francis, S. (2016) Power Relations among Institutions of Government In Nigeria's Presidential System: Issues and Contentions. Journal of Democracy, 19 (Number2), 124-137.

Gardiner, J.A. and Lyman, T.R. (1978), Decisions for Sale: Corruption and Reform in Land-Use and Building Regulation, Praeger, New York, NY.

Garten, M. (2016). The Role of Legislative Powers for Executive Corruption.

Halilu, B. I., Garba, A. B., \& Abdulmumin, A.(2015). Media Coverage of Corruption in Nigeria: An Analysis of the Sun and New Nigerian Newspapers. Nigeria, 1999-2007”, International Journal of Critical Accounting, Vol. 4 No. 3 , pp. 300-335.

Izah, P. P., \& Bello, A. (2013). Legislative oversight and democracy in developing countries. Paper for ECOWAS-P on Security Challenges and Political Instability in West Africa held in Dakar-Senegal from 29th-31st October.

Johnston, M. (2005), Syndromes of Corruption: Wealth, Power, and Democracy, Cambridge University Press, Cambridge.

Nwosu, N. I. (1998). The military and constitutional engineering in Nigeria. Ilorin Journal of

Odisu, T. A. (2016). The Nigerian legislature and the crisis of governance. Scientific Journal of Review, 5(9), $453-457$. 
Ogundiya, I. S. (2010). Corruption: The bane of democratic stability in Nigeria. Current Research Journal of Social Sciences, 2(4), 233-241.

Okeke, R. C., \& Idike, A. N. (2016). The Dialectics of Political Economy and Elite Corruption in A Postcolonial State: A Nigerian Case Study. Kuwait Chapter of the Arabian Journal of Business and Management Review, $5(7), 55$.

Oko, O. (2008). The Challenges of Democratic Consolidation in Africa. New Eng. L. Rev., 43, 165.

Olken, B. A (2009). Corruption perceptions vs. corruption reality," Journal of Public Economics, 93 (7-8), 950 \{964.

Olken, B. A.,(2007) Monitoring Corruption: Evidence from a Field Experiment in Indonesia," Journal of Political Economy, 115, 200\{249.

Olutola, O. F., \& Isaac, O. O. (2016). Legislative Corruption and the Challenges of Democratic Consolidation in Nigeria.

Onuigbo, R. A.(2015). Corruption in Nigeria: An Examination of Failed National Assembly Probes.

Opdenakker, R. (2006). Advantages and disadvantages of four interview techniques in qualitative research. In Forum Qualitative Sozialforschung/Forum: Qualitative Social Research (Vol. 7, No. 4).

Otusanya, O. J., Lauwo, S., Ige, O. J., \& Adelaja, O. S. (2015). Sweeping it under the carpet: the role of legislators in corrupt practice in Nigeria. Journal of Financial Crime, 22(3), 354-377.

Otusanya, O.J. (2010), "An investigation of tax evasion, tax avoidance and corruption in Nigeria",Unpublished Doctoral Thesis, University of Essex.

Otusanya, O.J. (2011), "Does democracy breed accountability? The role of state executives in Oyewo, O. (2007), "Constitutionalism and the oversight functions of the legislature in Nigeria", being a draft paper presented at African Network of Constitutional Law Conference on Fostering Constitutionalism in Africa, Nairobi

Pande, R. (2012). Corruption in Developing Countries," Annual Review of Economics, 4 (1), 479-509.

Pope, J. (2006), "Parliament and anti-corruption legislation", in Stapenhurst, R., Johnston, N. $\quad$ and Pelizzo, R. (Eds), The Role of the Parliament in Curbing Corruption, World Bank Publication.

Rose-Ackerman, S. (1999), Corruption and Government: Causes, Consequences, and Reform, Cambridge University Press, Cambridge Science, Vol. 48 No. 2, pp. 328-343.

Seer, D. (1967). The Meaning of Development. Brighton: Institute: UK, of Development Studies

Stapenhurst, R., Jacobs, K., \& Olaore, O. (2016). Legislative oversight in Nigeria: an empirical review and assessment. The Journal of Legislative Studies, 22(1), 1-29.

Stapenhurst, R., Johnston, N. and Pelizzo, R. (2006), The Role of Parliament in Curbing Corruption, The World Bank Institute, WA. Transparency International, 2015

The Punch newspaper, Lagos 23, March, 2010.

Transparency International (2001), Sourcebook, Transparency International, Washington, DC.

Transparency International. (2008). Corruption Perception Index 2008. Available from www.transparency.org

Uwak, U. E., \& Udofia, A. N. (2016). Corruption in Nigeria's Public Sector Organizations and Its Implications for National Development. Mediterranean Journal of Social Sciences, 7(3 S1), 27.Vol. 9 (2).

Warren, M.E. (2004), "What does corruption mean in a democracy?”, American Journal of Political 